ZOOLOGIA 27 (3): 324-330, June, 2010

doi: $10.1590 /$ S1984-46702010000300002

\title{
Guiana dolphins, Sotalia guianensis (Cetacea: Delphinidae), in the Paranaguá Estuarine Complex: insights on the use of area based on the photo-identification technique
}

\author{
Marcos C. de O. Santos; Júlia E. de F. Oshima; Eduardo dos S. Pacífico \& Ednilson da Silva
}

Projeto Atlantis, Laboratório de Biologia da Conservação de Cetáceos, Departamento de Zoologia, Instituto de Biociências da Universidade Estadual Paulista "Júlio de Mesquita Filho". Avenida 24-A 1515, Bela Vista, 13506-900 Rio Claro, São Paulo, Brazil, E-mail: sotalia@gmail.com

\begin{abstract}
The aim of the present study was to provide a preliminary description of habitat use by Guiana dolphins, Sotalia guianensis (Van Bénéden, 1864) in the Paranaguá Estuarine Complex (PEC), state of Paraná, Brazil. Approximately $124 \mathrm{~km}^{2}$ were surveyed by small boat from April 2006 to July 2008 in the following subsets of the PEC: Canal do Superagui $\left(\sim 28 \mathrm{~km}^{2}\right)$; Pinheiros Bay $\left(\sim 34 \mathrm{~km}^{2}\right)$; part of Laranjeiras Bay, which included the Guaraqueçaba sub-estuary $\left(\sim 38 \mathrm{~km}^{2}\right)$; and part of the Mixture Section of the PEC $\left(\sim 24 \mathrm{~km}^{2}\right)$. Our efforts were unevenly distributed in the study area. During 55 survey days covering seven distinct seasons, we spent 165 hours observing 323 groups of S. guianensis. Group size varied from two individuals to aggregations as large as approximately 100 dolphins. A total of 49,921 photographs were analyzed; 15,038 (30\%) were considered useful for identification purposes. A total of 182 individuals were catalogued, from which $122(67 \%)$ were cataloged in the last three seasons, when the surveyed area was expanded. The number of individual sightings in distinct days varied from one to 16. A total of 94 individuals (51.6\%) were re-sighted at least once. From the 37 individuals cataloged in the first season, 18 (48.6\%) were re-sighted in the last season. Eleven individuals with 5+ sightings were always observed in the same subset of the estuary, including an individual with 13 sightings. Sixteen individuals with three to 16 sightings were observed in three of the four estuary subsets surveyed. An individual cataloged in May 2002 in a pilot study was re-sighted up to August 2006. Our preliminary results correspond to the first evidence of site fidelity for several monitored individuals; it also revealed, for the first time, the flexibility of movements throughout the entire estuarine complex by several other individuals
\end{abstract}

KEY WORDS. Habitat use; site fidelity; cetaceans; ecology.

The Guiana dolphin - Sotalia guianensis (Van Bénéden, 1864 ) - is found in coastal and estuarine waters of the western South Atlantic, from southern Brazil to Honduras (Flores 2002). During the past 15 years, several populations have been surveyed using photo-identification, which has rendered important information on ecological aspects such as site fidelity, movements, and social organization (see Flores 1999, SANTOS et al. 2001, Azevedo et al. 2004, 2005, 2007, Flores \& Bazzalo 2004, Flores \& Fontoura 2006, Rossi-Santos et al. 2007, Santos \& Rosso 2007, 2008). Even after all these efforts, the species remains listed as "data deficient" by the World Conservation Union (ReEves et al. 2003, IUCN 2009).

In the southern part of its range, specifically around the Cananéia island $\left(\sim 25^{\circ} 00^{\prime} \mathrm{S}, 47^{\circ} 50^{\prime} \mathrm{W}\right)$ and adjacent areas inserted in the Lagamar estuary, S. guianensis has been the focus of several studies since the 1990s, including behavior (Monteiro-Filho 1995, SANTOS et al. 2000), feeding habits (SANTOS et al. 2002), age estimation (SANTOs et al. 2003), contaminant loads (Yogui et al.
2003), acoustics (PIVAri \& Rosso 2005), group size and composition (SANTOS \& Rosso 2007), and social organization (SANTOS \& Rosso 2008). Sotalia guianensis is also found in the southern range of the Lagamar estuary, more precisely in the Paranaguá Estuarine Complex (PEC) $\left(2^{\circ} 24^{\prime} \mathrm{S}, 48^{\circ} 24^{\prime} \mathrm{W}\right)$ sensu NoERnBerg et al. (2006). For this portion of the species' range, there are only a few published studies based on stranded and incidentally captured individuals (e.g. Rosas \& Monteiro-FilHo 2002, Rosas et al. 2003).

Due to their ecological importance, several areas of the Lagamar estuary were designated as protected reserves in the 1980s (see SchaEfFER-Novelli et al. 1990, IPARDEs 2001). However, anthropogenic factors are causes of concern for the protection of this ecosystem. Although prohibited by Brazilian law since 1985 , chlorinated hydrocarbons were widely used until the end of the 1990s; these pollutants continue to contaminate the estuary (Ferreira et al. 1980, Yogui et al. 2003). The Paranaguá harbour, Brazil's second most important port, was built in 1935 
in the southern portion of the Lagamar estuary. Oil spills are quite common in this area. As top-level predators, small cetaceans are exposed to and affected by persistent organic pollutants (POP) including polychlorinated biphenyls (PCBs), dibenzo-p-dioxins (PCDDs), dibenzofurans (PCDFs) and related compounds (Ross et al. 1996, Ross 2002). The presence of the lobomycosis-like disease in a population of $S$. guianensis from the Paranaguá estuary was recently reported (VAN BREsSEN et al. 2009). The absence of lobomycosis-like in the population inhabiting the Cananéia area called our attention because this disease is likely to be contagious. The aim of the present study was to give a preliminary description of the characteristics of habitat use by $S$. guianensis in the southern range of the Lagamar estuary, based on the application of the photo-identification technique (see Würsig \& WürsIG 1977).

\section{MATERIAL AND METHODS}

The PEC $\left(25^{\circ} 15^{\prime}-25^{\circ} 36^{\prime} \mathrm{S}, 48^{\circ} 02^{\prime}-48^{\circ} 45^{\prime} \mathrm{W}\right)$ is a large, in terconnected subtropical estuarine system comprised of two main bodies of water (LANA et al. 2001). It has $3,870 \mathrm{~km}^{2}$ of watershed area, of which $551.8 \mathrm{~km}^{2}$ correspond to the main body of water (Noernberg et al. 2006). The PEC is formed by five smaller sections including four main bays (Antonina, Paranaguá, Laranjeiras, Pinheiros) and a Mixture Section (Fig. 1). The Laranjeiras Bay is formed by four sub-estuaries: Medeiros, Itaqui, Benito and Guaraqueçaba (Noernberg et al. 2006). The present study was conducted at the Pinheiros Bay, as well as in a section of the Laranjeiras Bay, including the whole sub-estuary of Guaraqueçaba, and in a section of the Mixture Section, which is in close connection with two islands,

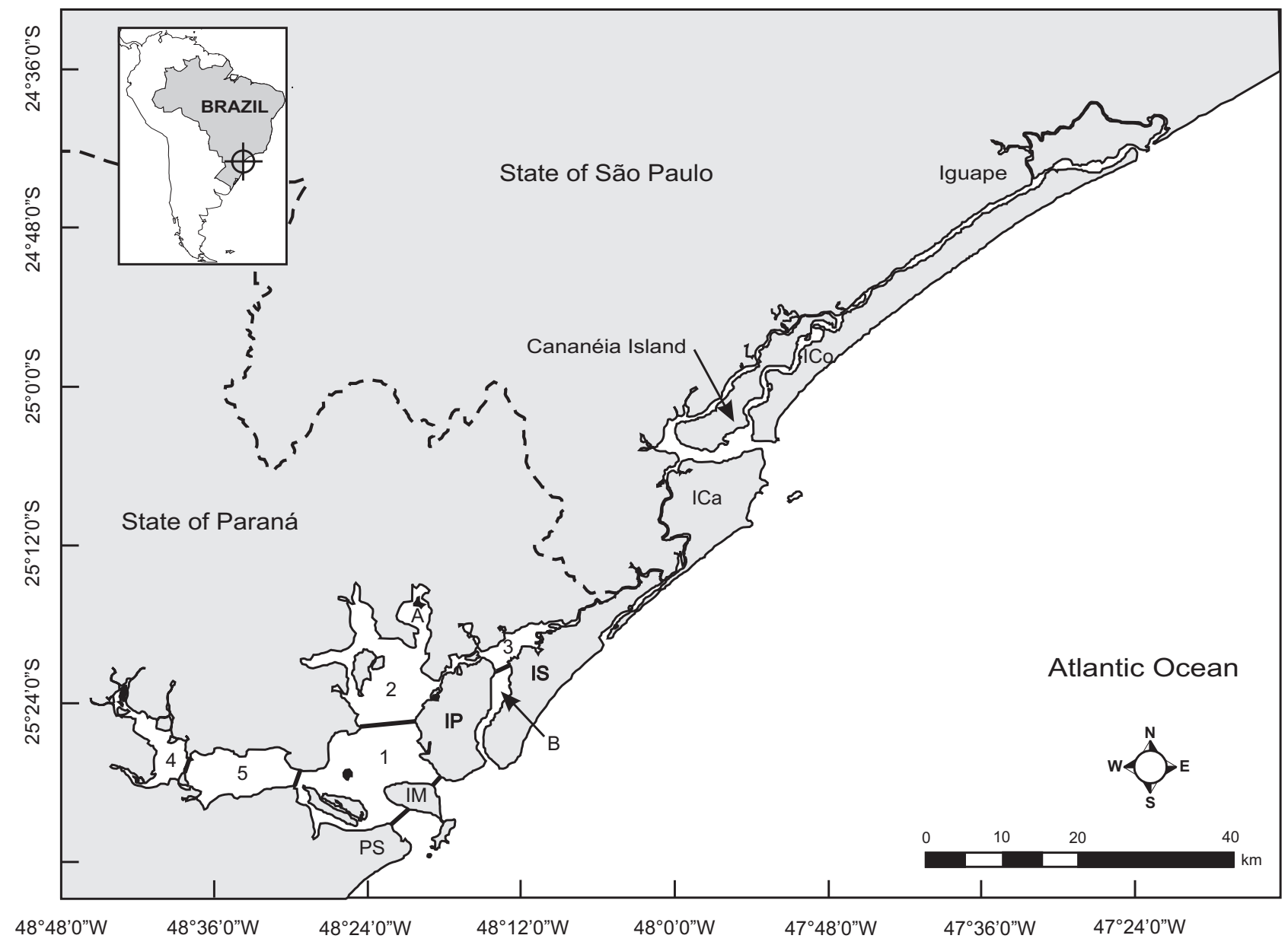

Figure 1. The Lagamar estuary, from Iguape, São Paulo State, to Pontal do Sul (PS), Paraná State, and the Paranaguá Estuarine Complex. Sectors: (1) Mixture Zone, (2) Laranjeiras, (3) Pinheiros, (4) Antonina, (5) Paranaguá; sub-estuaries: (A) Guaraqueçaba, (B) Canal do Superagui, (IM) Ilha do Mel, (IP) Ilha das Peças, (IS) Ilha do Superagui, (ICa) Ilha do Cardoso, (ICo) Ilha Comprida. Modified from NOERNBERG et al. (2006). 
Ilha das Peças and Ilha do Mel (Fig. 1). A pilot study was conducted from 2000 to 2002, when we opted to split the Pinheiros Bay into two survey areas, which we named "Canal do Superagui", and "Pinheiros Bay". The 14-km long channel connecting the main body of water from the Pinheiros Bay to the coastal waters represents the "Canal do Superagui" (Superagui channel). The remaining area represents the "Pinheiros Bay". Therefore, a total area of about $124 \mathrm{~km}^{2}$ of the PEC was surveyed in the following four subsets: 1) Canal do Superagui (named "Canal" in the present study, $28 \mathrm{~km}^{2}$ ), 2) "Pinheiros" Bay $\left(\sim 34 \mathrm{~km}^{2}\right)$, part of Laranjeiras Bay, which included the Guaraqueçaba sub-estuary and was named 3) "Laranjeiras" in this study $\left(\sim 38 \mathrm{~km}^{2}\right)$, and part of the Mixture Section close to Ilha das Peças named 4) "Peças" in this study $\left(\sim 24 \mathrm{~km}^{2}\right)$ (see Fig. 1). There are no biological and/or physical barriers isolating these four sub-areas. They were stratified in order to cover a significant part of the area where $S$. guianensis can be found in minimum amount of days. Two subsets of the estuary were usually surveyed at a given day.

From April 2006 to July 2008, boat-based (15 hp motorized vessel) surveys were conducted between six and 12 distinct days per season in the following sequence: fall, winter and spring of 2006, summer and winter of 2007, and summer and winter of 2008. Seasons were divided as follows: summer (December-February), fall (March-May), winter (June-August), and spring (September-November). Efforts were not evenly distributed temporally or spatially. All subsets, but the Mixture Section, were surveyed in all seasons. The latter was included in surveys mainly from the winter of 2007 on. Surveys were conducted when sea conditions were good (Beaufort Scale $\leqslant 2$ ).

The survey path followed a zig-zag pattern to maximize the chances of encountering dolphins. A group of Guiana dolphins was defined as any aggregation of two or more individuals, including female-calf pairs, observed in close proximity to each other within a radius of approximately $50 \mathrm{~m}$. These aggregations were often, but not always, engaged in similar activities. A calf was defined as an individual up to a half the length of an adult, swimming beside and slightly behind an adult. Adults were sexed as females when they were observed consistently in the company of a calf during 3+ distinct seasons. Observed behaviors were grouped into four major categories: feeding, traveling, socializing, and resting (sensu SHANe 1990). Dolphin behavior was collected in an ad libitum manner (Altmann 1974, ManN 1999), every five minutes.

A $35 \mathrm{~mm}$ reflex digital camera with a $400 \mathrm{~mm}$ lens was used to photograph the dolphins in the field. After all individuals in a group were photographed, the boat moved to the previous route to find more groups and to cover the remaining area of the specific surveyed subset of the estuary on that day. The quality of the photographs was analyzed following the protocol described in SANTOS \& Rosso (2008). We took each digital image and displayed it on a computer screen without the aid of software to match dorsal fins. Each individual with distinct notches on the dorsal fin was catalogued and compared with subsequent photographs of marked individuals. Individual archives were created with the following data: date of sighting; number of notches in the trailing edge; number of notches on the top; any other distinguishable permanent mark; geographic coordinates; location (subset of the estuary); group size; presence of calves; identified congeners; number of the best photograph taken on that day. The total number of sightings of each individual was counted and plotted considering the six seasons. In this case, sightings on the same day were excluded. A rate of discovery curve was also plotted based on new inclusions in the catalog throughout the seven monitored seasons.

\section{RESULTS}

During 55 days of surveys, 165 hours were spent observing 323 groups of S. guianensis in the PEC (Tab. I). Most groups were observed in the Laranjeiras, Canal and Pinheiros subsets (Fig. 2). Group size varied from two individuals to aggregations as large as approximately 100 individuals.

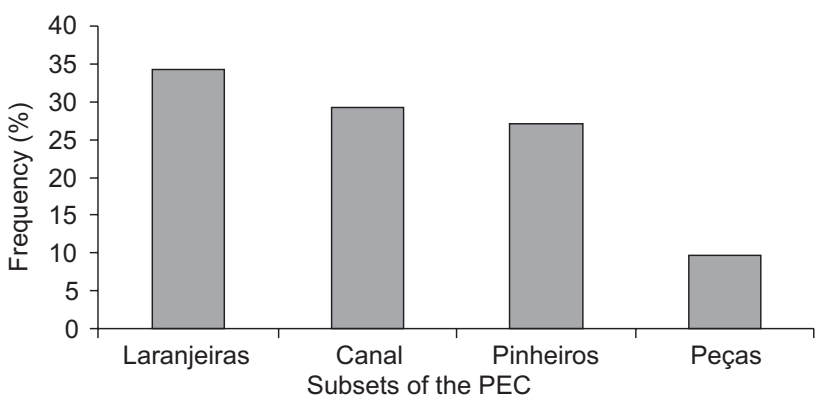

Figure 2. Frequency of occurrence of S. guianensis groups observed in four distinct subsets of the Paranaguá Estuarine Complex (PEC), Brazil, between April 2006 and July 2008.

Table I. Group size of S. guianensis observed in four subsets of the Paranaguá Estuarine Complex (PEC) from April 2006 to July 2008.

\begin{tabular}{lccc}
\hline $\begin{array}{c}\text { Subsets of } \\
\text { the PEC }\end{array}$ & $\begin{array}{c}\text { Number of } \\
\text { groups }\end{array}$ & Mean \pm SD & $\begin{array}{c}\text { Range (number } \\
\text { of individuals) }\end{array}$ \\
\hline Canal & 94 & $6.5 \pm 8.2$ & $1-60$ \\
Pinheiros & 88 & $13.7 \pm 18.9$ & $1-80$ \\
Laranjeiras & 110 & $16.6 \pm 18.6$ & $1-100$ \\
Peças & 31 & $21.6 \pm 22.8$ & $5-90$ \\
Overall & 323 & $11.5 \pm 14.4$ & $1-100$ \\
\hline
\end{tabular}

A total of 49,921 photographs were analyzed; 30\% were considered suitable for identification purposes. One hundred 
and eighty-two individuals were identified from natural dorsal fin markings. Three individuals had mutilated dorsal fins or flukes (Figs 3-5). These wounds were likely caused either by shark bites or by anthropogenic activities that resulted from interactions with gillnets.
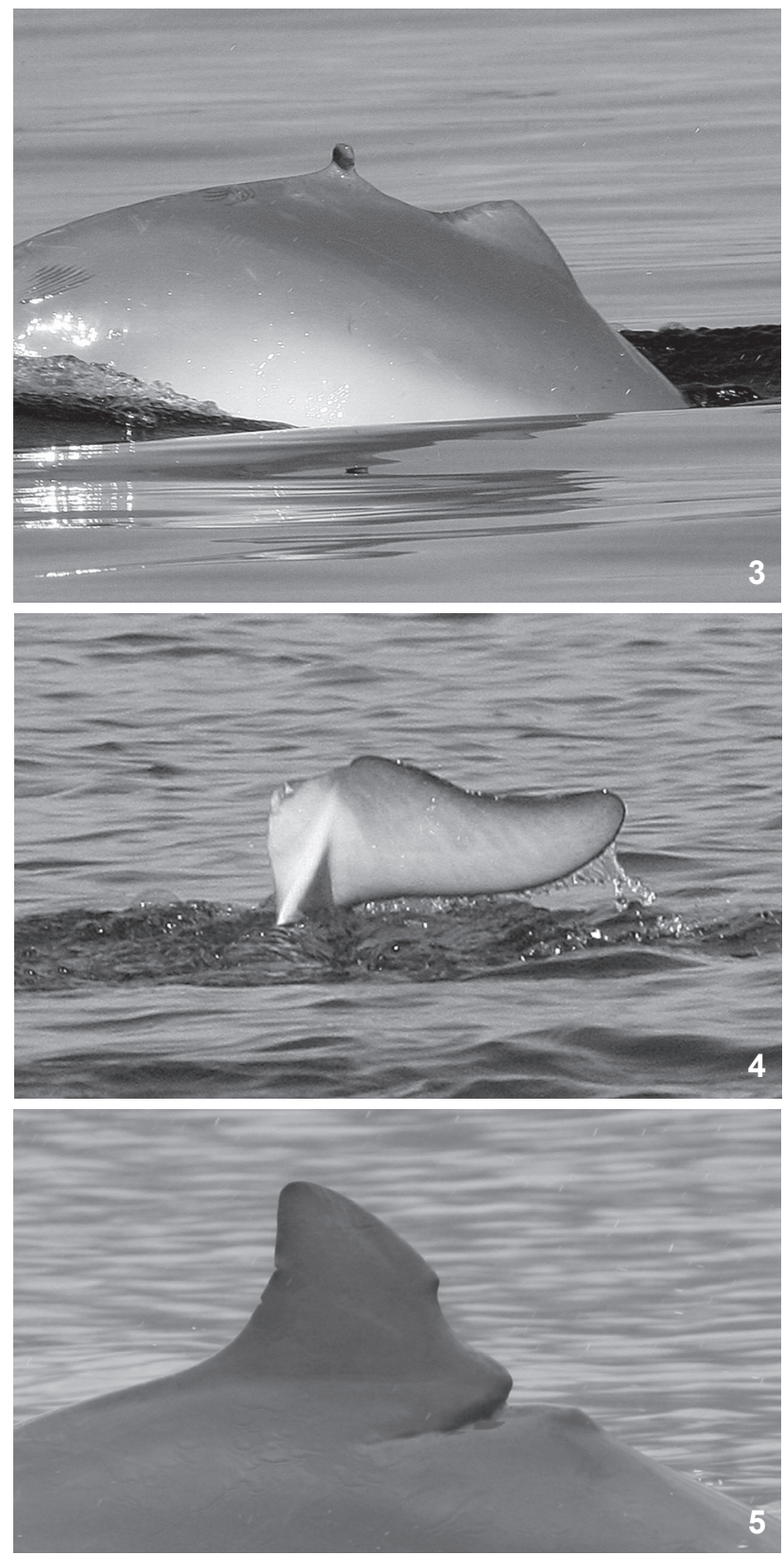

Figures 3-5. Sotalia guianensis photo-identified in the Paranaguá Estuarine Complex, Brazil, showing different mutilations: (3) without dorsal fin and with shark teeth marks, (4) without one fluke, and (5) with deep wound likely a result of gillnet entanglement.
As expected, the expansion of the survey area during the last three seasons resulted in a $67 \%(\mathrm{n}=122)$ increase in the number of new dolphins photo-identified (Fig. 6). Over $51 \%$ ( $\mathrm{n}=94)$ of photo-identified individuals were re-sighted. Individual sighting frequencies ranged from 1 to 16 days (Fig. 7). Eleven individuals with 5+ sightings, including an individual with 13 sightings, were always observed in the same subset of the estuary. Sixteen individuals with three to 16 sightings were observed in three of the four surveyed subsets of the estuary, using both main water bodies. Out of 37 individuals photoidentified in the first season, $49 \%(n=18)$ were re-sighted during the last season. An individual cataloged in May 2002 during the pilot study was re-sighted in August 2006.

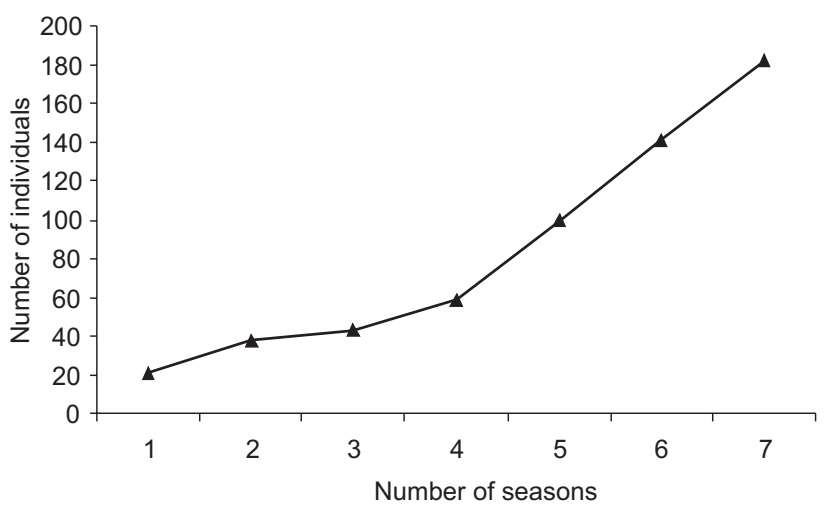

Figure 6. Rate of discovery curve for S. guianensis photo-identified in distinct seasons in the Paranaguá Estuarine Complex, Brazil between April 2006 and July 2008.

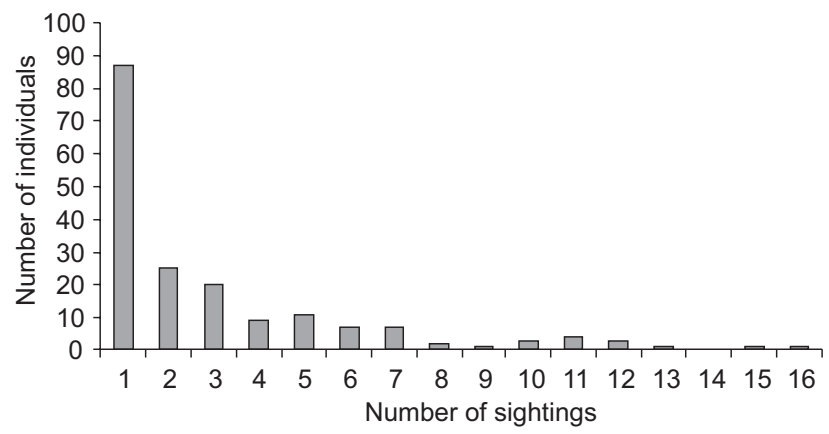

Figure 7. Frequency of sightings of $S$. guianensis photo-identified in seven distinct seasons in the Paranaguá Estuarine Complex, Brazil, between April 2006 and July 2008.

\section{DISCUSSION}

In order to conduct a preliminary investigation of the use of the area by $S$. guianensis in the PEC, four subsets of the estuary were surveyed. Due to time and budget, it was not 
possible to survey the entire $550 \mathrm{~km}^{2}$ of the PEC watershed. Efforts were invested in $124 \mathrm{~km}^{2}$, which represents $22.5 \%$ of the whole area. Up to the last three seasons, efforts were concentrated in the Laranjeiras and Pinheiros bays, as well in the Canal do Superagui subsets. As the research team got acquainted with the site, it was possible to expand the surveyed subsets to the Mixture Zone sensu Noernberg et al. (2006), called Peças in this study. As a result of the latter addition, 82 individuals were added to the catalog, representing $45 \%$ over all cataloged individuals (Fig. 2). Although only 31 groups (9.6\% overall) were photographed in the Peças subset, they were usually larger (see Tab. I), which resulted in a considerable number of individuals being included in the catalog. Future survey efforts should concentrate in the same subsets to check the tendency of the discovery curve. On the other hand, a significant increase of cataloged individuals in newly investigated areas may indicate preferences in the use of the area and provide clues on the characteristics of the social organization of the surveyed population.

Our preliminary results correspond to the first evidence of site fidelity for several monitored individuals $(n=11)$; it also revealed, for the first time, the flexibility of movements throughout the entire estuarine complex by several other individuals ( $\mathrm{n}$ =16). One of the first cataloged individuals, sighted for the first time in May 2002, was still found in the local estuary four years later, always at Pinheiros Bay. Those individuals sighted in three different subsets of the estuary moved between the two main water bodies (see Fig. 1). The pathway used for such movements is unknown. Dolphins could move through inner channels or use coastal waters. When choosing the latter, Guiana dolphins are at risk of predation. One of the cataloged individuals was a victim of a predatory attempt, confirmed by the wound of a shark bite on the body (Fig. 3). The wound had already healed when the cataloged dolphin was sighted for the first time and no clues were available regarding where the attack took place. Sharks are known to occur in coastal waters with occasional incursions into inner estuarine waters (SADOWSKy 1971, Heithaus 2001). Surveys along the coast would be interesting in order to check for dolphin displacements to outer waters.

Two recognizable individuals had injuries to parts of their body. No conclusion was reached on the possible cause of the mutilated fluke showed in figure 4 . The healed area resembles the cut-like wound observed in a Guiana dolphin showed by AzEvedo et al. (2008). The authors attributed the cut-like wound to the release from a gillnet after an incidental capture at the Guanabara Bay, Rio de Janeiro $\left(\sim 22^{\circ} \mathrm{S}\right)$. The damage observed in figure 4 was either caused by a predator or by a propeller. The injured individual was sighted on 11 different occasions in a small range of the Pinheiros Bay, always followed by a calf. Was the fluke mutilation responsible for a smaller range of the injured dolphin? Was the Pinheiros Bay preferred by this mutilated dolphin because of its injuries? A longer-term study may help answering such questions. Comparisons of movements displayed by other mutilated $S$. guianensis would also represent an important clue to answer such questions. The mutilation presented by another cataloged individual in figure 5 is likely to be the result of an interaction with gillnets. AzEvedo et al. (2008) showed a photograph of an individual with similar wounds in the Guanaraba Bay, but on that occasion, the injured individual entangled in a rope. The adult dolphin sighted in the PEC was first sighted on April 2006; it was re-sighted on February 2008 in the company of a newborn calf. Although the use of gillnets is not allowed in the inner waters of the PEC (IPARDes 2001), we witnessed their use on several occasions, mainly in the Laranjeiras Bay.

Site fidelity of S. guianensis had been observed in other locations throughout the species distribution (e.g. FLORES 1999, SANTos et al. 2001, Azevedo et al. 2004, Rossi-SANTos et al. 2007). Therefore, we expected to find evidence of site fidelity in our short-term, preliminary study. However, relatively long-distance movements between the two main water bodies were not expected. Future studies should compare the recent photo-identification catalog gathered in the PEC with another one in an update process gathered in the northern range of the Lagamar estuary, more precisely the Cananéia estuary. Other population parameters of the surveyed population in the PEC are under investigation based on photo-identification efforts, such as abundance and social organization both. The forthcoming results of a longer-term study are important to understand the dynamics on the use of the area by the cataloged dolphins. As an important element of the trophic level in a highly productive ecosystem, the knowledge on a flagship species like $S$. guianensis will represent an important tool for the PEC conservation purposes.

\section{ACKOWLEDGEMENTS}

Fundação de Amparo à Pesquisa do Estado de São Paulo (FAPESP) provided grants through "Programa Jovem Pesquisador" (process 05/59439-5 and 05/54149-9). The Earthwatch Institute funded equipment used in the field. Grants were provided by Cetacean Society International and the Whale and Dolphin Conservation Society for photo-identification studies. Support in the field was provided by the Instituto Oceanográfico da Universidade de São Paulo, as well as the Núcleo Pro-Ação, Guaraqueçaba - Pontifícia Universidade Católica do Paraná. Júlia Oshima and Eduardo Pacífico received grants from the Agência Nacional do Petróleo (ANP), Financiadora de Estudos e Projetos (FINEP), Ministério da Ciência e Tecnologia (MCT), Programa de Recursos Humanos da ANP para o setor de petróleo e gás PRH-ANP/MCT. Michael Heithaus and Otto B.F. Gadig reviewed the photographs showing the shark bite on a Guiana dolphin. We thank the reviewers for their contributions to this manuscript. Dagmar Fertl (Ziphius EcoServices) kindly reviewed the final draft of this manuscript and worked meticulously on the text flow of this final version. 


\section{LITERATURE CITED}

Altmann, J. 1974. Observational study of behavior: sampling methods. Behaviour 49: 227-267.

Azevedo, A.F.; J. Laílson-Brito; H.A. Cunha \& M. Van Sluys. 2004. A note on site fidelity of marine tucuxis (Sotalia fluviatilis) in Guanabara Bay, southeastern Brazil. Journal of Cetacean Research and Management 6 (3): 265-268.

Azevedo, A.F.; S.C. Viana; A.M. Oliveira \& M. Van Sluys. 2005. Group characteristics of marine tucuxis (Sotalia fluviatilis) in Guanabara Bay, south-eastern Brazil. Journal of the Marine Biological Association 85 (1): 209-212.

Azevedo, A.F.; A.M. Oliveira; S.C. Viana \& M. Van Sluys. 2007. Habitat use by marine tucuxis (Sotalia guianensis) (Cetacea: Delphinidae) in Guanabara Bay, south-eastern Brazil. Journal of the Marine Biological Association 87 (1): 201-205.

Azevedo, A.F.; J. Laílson-Brito; P.R. Dorneles; M. Van Sluys; H.A. Cunha \& A.B.L. Fragoso. 2008. Human-induced injuries to marine tucuxis (Sotalia guianensis) (Cetacea: Delphinidae) in Brazil. JMBA - 2, Biodiversity Records. Available online at: http://www.mba.ac.uk/jmba/jmba2biodiversityrecords.php [Acessed: 21/VI/2008].

Ferreira, J.R.; Prado Filho, L.G. \& L.A.B. Castro 1980. Alguns dados sobre a poluição por pesticidas clorados na região lagunar estuarina de Cananéia. Boletim do Instituto de Pesca 7 (2): 103-109.

FLORES, P.A.C. 1999. Preliminary results of a photoidentification study of the marine tucuxi, Sotalia fluviatilis, in southern Brazil. Marine Mammal Science 15 (3): 840-847.

Flores, P.A.C. 2002. Tucuxi Sotalia fluviatilis, p. 1267-1269. In: W.F. Perrin; B. WÜrsig \& J.G.M. TheWISSEN (Eds). Encyclopedia of Marine Mammals. San Diego, Academic Press, 1414p.

Flores, P.A.C. \& M. BAzZALo. 2004. Home ranges and movement patterns of the marine tucuxi dolphin, Sotalia fluviatilis, in Baía Norte, Southern Brazil. Latin American Journal of Aquatic Mammals 3 (1): 37-52.

Flores, P.A.C. \& N. Fontoura. 2006. Ecology of marine tucuxi, Sotalia guianensis, and bottlenose dolphin, Tursiops truncatus, in Baía Norte, Santa Catarina state, southern Brazil. Latin American Journal of Aquatic Mammals 5 (2): 105-115.

Heithaus, M.R. 2001. Predator-prey and competitive interactions between sharks (order Selachii) and dolphins (suborder Odontoceti): a review. Journal of Zoology, London 253 (1): 53-68.

IpaRdes. 2001. Zoneamento da Área de Proteção Ambiental de Guaraqueçaba. Curitiba, Instituto Paranaense de Desenvolvimento Econômico e Social, vol. 1, 254p.

IUCN. 2009. 2009 IUCN Red List of Threatened Species. Available online at: http://www.iucnredlist.org. [Acessed: 23/IV/2009].

Lana, P.C.; E. Marone; R.M. Lopes \& E.C. Machado. 2001. The subtropical estuarine complex of Paranaguá Bay, Brazil, p. 131-145. In: U. Seeliger \& B. KJeRFVe (Eds). Coastal marine ecosystems of Latin America. Berlin, Springer Verlag, 360p.
ManN, J. 1999. Behavioral sampling methods for cetaceans: a review and critique. Marine Mammal Science, 15 (1): 102122.

Monteiro-Filho, E.L.A. 1995. Pesca interativa entro o golfinho Sotalia fluviatilis guianensis e a comunidade pesqueira da região de Cananéia. Boletim do Instituto de Pesca 22: 15-23.

Noernberg, M.A.; L.F.C. Lautert; A.D. Araújo; E. Marone; R. Angelotti; J.P.B. Netto Jr \& L.A. Krug. 2006. Remote sensing and GIS integration for modelling the Paranaguá estuarine complex - Brazil. Journal of Coastal Research39 (Special Issue): 1627-1631.

PIVAri, D. \& S. Rosso. 2005. Whistles of small groups of Sotalia fluviatilis during foraging behavior in southeastern Brazil. Journal of the Acoustical Society of America 118 (4): 27252731.

Reeves, R.R.; B.D. Smith; E.A. Crespo \& G.Notarbotolo di Sciara. 2003. Dolphins, whales and porpoises: 2002-2010 Conservation Action Plan for the World's Cetaceans. Gland, The World Conservation Union, IUCN, 147p.

Rosas, F.C.W. \& E.L.A. Monteiro-Filho. 2002. Reproduction of the estuarine dolphin (Sotalia guianensis) on the coast of Paraná, Southern Brazil. Journal of Mammalogy 83 (2): 507-515.

Rosas, F.C.W.; A.S. Barreto \& E.L.A. Monteiro-Filho. 2003. Age and growth of the estuarine dolphin (Sotalia guianensis) (Cetacea, Delphinidae) on the Paraná coast, southern Brazil. Fishery Bulletin 101 (2): 377-383.

Ross, P.S. 2002. The role of immunotoxic environmental contaminants in facilitating the emergence of infectious diseases in marine mammals. Human and Ecological Risk Assessment 8 (2): 277-292.

Ross P.S.; De Swart, R.L; Van Loveren, H.; Osterhaus, A.D.M.E. \& J.G. Vos. 1996. The immunotoxicity of environmental contaminants to marine wildlife: a review. Annual Review of Fish Diseases 6 (2): 151-165.

Rossi-SAntos, M.; L.L. Wedekin \& E.L.A. Monteiro-Filho. 2007. Residence and site fidelity of Sotalia guianensis in the Caravelas River estuary, Bahia State, Northeastern Brazil. Journal of the Marine Biological Association 87 (1): 207-212.

SADOwsKy, V. 1971. Notes on the bull shark Carcharhinus leucas in the lagoon region of Cananéia, Brazil. Boletim do Instituto Oceanográfico 20 (1): 71-78.

SANTOS, M.C. DE O. \& S. Rosso. 2007. Ecological aspects of marine tucuxi dolphins (Sotalia guianensis) based on group size and composition in the Cananéia estuary, southeastern Brazil. Latin American Journal of Aquatic Mammals 6 (1): 71-82.

SANTOS, M.C. DE O. \& S. Rosso. 2008. Social organization of marine tucuxi dolphins, Sotalia guianensis, in the Cananéia estuary of southeastern Brazil. Journal of Mammalogy 88 (2): 347-355.

Santos, M.C. de O.; S. Rosso; S. Siciliano; A.N. Zerbini; E. Zampirolli; A. Vicente \& F. Alvarenga. 2000. Behavioral observations of the marine tucuxi dolphin (Sotalia fluviatilis) in São Paulo estuarine waters, Southeastern Brazil. Aquatic Mammals 26 (3): 260-267. 
Santos, M.C. De O.; L.B. Acuña \& S. Rosso. 2001. Insights on site fidelity and calving intervals of the marine tucuxi dolphin (Sotalia fluviatilis) in south-eastern Brazil. Journal of the Marine Biological Association 81 (6): 1049-1052.

Santos, M.C. De O.; S. Rosso; R. A. Santos; S.H.B. Lucato \& M. BAssoI. 2002. Insights on small cetacean feeding habits in southeastern Brazil. Aquatic Mammals 28 (1): 38-45.

Santos, M.C. de O.; S. Rosso \& R.M.A. Ramos. 2003. Age estimation of marine tucuxi dolphins (Sotalia fluviatilis) in south-eastern Brazil. Journal of the Marine Biological Association 83 (1): 233-236.

Schaeffer-Novelli, Y.; H.S.L. Mesquita \& G. Cintrón-Molero. 1990. The Cananéia lagoon estuarine system, São Paulo, Brazil. Estuaries 13 (2): 193-203.

SHANE, S. 1990. Behavior and ecology of the bottlenose dolphin at Sanibel Island, Florida, p. 245-265. In: S. LEATHERwood \& R.R. Reeves (Eds). The Bottlenose Dolphin. San Diego, Academic Press, 572p.

Van Bressem, M.; Santos; M. C. De O. \& J. E. F. Oshima. 2009. Skin diseases in Guiana dolphins (Sotalia guianensis) from the Paranaguá estuary, Brazil: A possible indicator of a compromised marine environment. Marine Environmental Research 67 (1): 63-68.

WÜRSIG, B. \& M. WÜrsIG. 1977. The photographic determination of group size, composition, and stability of coastal porpoises (Tursiops truncatus). Science 198(4318): 755-756.

Yogui, G.T.; M.C. DE O. SAntos \& R.C. Montone. 2003. Chlorinated pesticides and polychlorinated biphenyls in marine tucuxi dolphins (Sotalia fluviatilis) from the Cananéia estuary, southeastern Brazil. The Science of the Total Environment 312 (1-3): 67-78.

Submitted: 06.I.2009; Accepted: 23.III.2010.

Editorial responsibility: Paulo da Cunha Lana 